\title{
Welding Technology Development for an Erosion-Resistant Slurry Pipeline Steel
}

\author{
An investigation into the welding technology enabling the deployment \\ of an erosion-resistant pipeline steel in the oil sands mining \\ industry to achieve significant cost savings
}

\author{
BY X. YUE, A. J. WASSON, T. D. ANDERSON, N. MA, D. P. FAIRCHILD, AND H. JIN
}

\begin{abstract}
A new erosion-resistant high-manganese steel (HMS) was developed for use as a slurry pipeline material in the oil sands mining industry. This paper describes the parallel development of the welding technology (welding consumable, welding procedures) for the HMS pipe. Thermodynamic simulation, design of experiments (DoE), experimental welding, and physical testing were used to formulate and optimize the welding consumable, which has a unique combination of superior strength, toughness, erosion resistance, and weldability. Welding procedures were developed for the new application and were qualified per the project specification and industry code. Advanced microstructure analysis was conducted to assist the welding development effort. The welding technology has recently been applied in the field for the fabrication of a HMS slurry pipeline. It is anticipated that these developments will provide significant cost savings to the oil sands industry.
\end{abstract}

\section{KEYWORDS}

- Erosion-Resistant High-Manganese Steel

- Oil Sands Mining • Welding Consumable Development

- Design of Experiments • Thermodynamic Simulation

- Welding Procedures Development and Qualification

\section{Introduction}

In the oil sands mining industry, piping systems are used to transport mixtures of solid rocks, sand, water, and bitumen in a liquid slurry to a processing plant for oil extraction after which additional pipelines carry the erosive debris back to the mining site or to a storage area (Ref. 1). For a large operation, these piping systems may cover tens, or perhaps, a hundred kilometers. Current slurry hydrotransport pipes are typically made of low-carbon, pipeline-grade steel (e.g., API specification 5L X65 or X70), as shown in Fig. 1A. The slurry pipelines are subjected to significant abrasive/erosive wear and corrosion. This causes pipe wall loss, as shown in
Fig. 1B, and leads to frequent repairs and replacements. As such, these piping systems are often the source of significant operational costs. Various materials, such as martensitic stainless steels, bimetallic hardened-steel products, tungsten or chromium carbide based hardfacing materials, and polymer-lined materials (polyurethane), have been evaluated and used by oil sands mining operators. However, such materials have not achieved widespread application due to either relatively poor wear/erosion performance, high material/fabrication costs, or limited material thicknesses. Slurry pipeline erosion and degradation remains a challenge for the industry, and alternative pipe materials are sought to reduce cost and increase operational efficiency (longer service life) (Refs. 2-13).

ExxonMobil and South Korean steel maker Pohang Iron and Steel Co. Ltd. (POSCO) have collaborated in the development of a new high-manganese steel (HMS) for slurry pipeline service. This steel demonstrates excellent erosion/ wear/corrosion performance (Ref. 14). The nominal composition of the steel is $1.2 \mathrm{wt}-\% \mathrm{C}, 18 \mathrm{wt}-\% \mathrm{Mn}, 3 \mathrm{wt}-\% \mathrm{Cr}, 0.5$ wt-\% $\mathrm{Cu}$, and $0.1 \mathrm{wt}-\% \mathrm{Si}$ [hereafter, \% denotes wt-\%]. It is highly work hardenable and has been engineered to incur in situ surface modification that enhances erosion resistance during slurry pipeline service. To enable use of this HMS as a slurry pipeline material, girth welding technology is needed for field fabrication. No commercial technology (consumables, procedures, etc.) meeting the performance targets is available; therefore, a welding development program was undertaken and this included formulation and manufacture of a new consumable wire. Several performance targets were pursued. First, the welds must provide the necessary strength and toughness, including Charpy testing at $-29^{\circ} \mathrm{C}$. Since the girth welds are exposed to slurry transport during service, they need to have good erosion performance. Additionally, the welds must possess adequate weldability for field fabrication and because the HMS chemistry solidifies as primary austenite, solidification cracking was a particular concern.

Before embarking on a computational and experimental consumable development program, a literature review was conducted (Refs. 15-22). Reference 15 is notable for its 

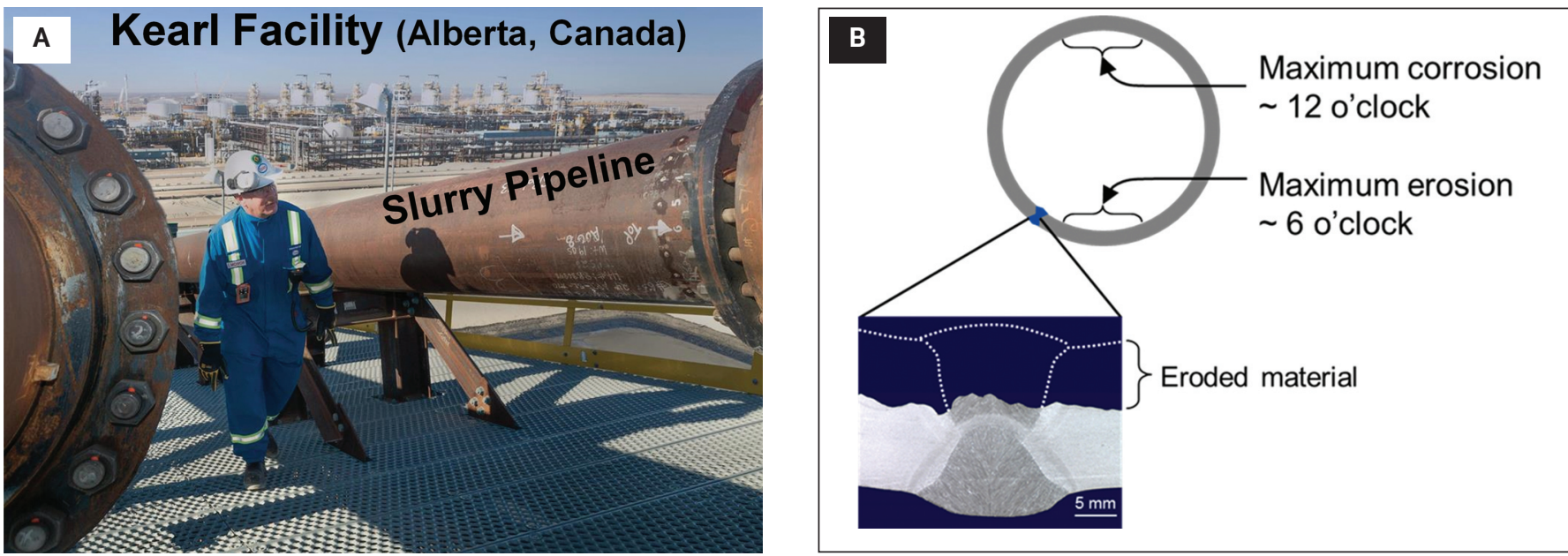

Fig. 1-A - Slurry pipelines at the Kearl facility in Alberta, Canada; B - cross section of carbon steel slurry pipe near seam weld showing service-related erosion.
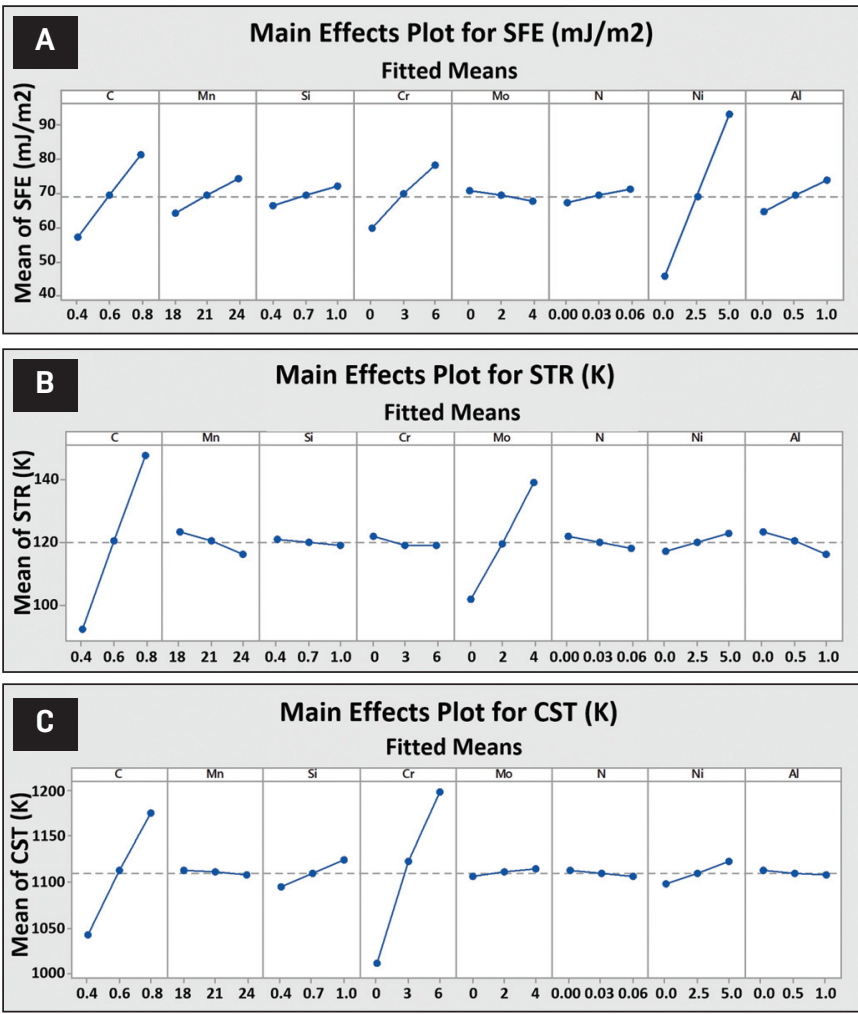

Fig. 2 - Effect of alloying elements on the three thermodynamic parameters. A - SFE; B - STR; C - CST.

breadth, observations, conclusions, and for the fact that it was dated 1954. It is perhaps the earliest comprehensive study of HMS technology and welding including a review of early patents from the 1920s and ' 30 s. Reference 15 focused on 10-14\% Mn alloys (Hadfield-type steels), yet many observations are still relevant to a broader classification of HMS alloys like the slurry pipeline chemistry. The challenge of carbide precipitation and the negative effects on toughness were well covered. Warnings were given to apply welding "... with as little heating of the base metal as possible." Furthermore, "bead cracking" (i.e., solidification cracking)

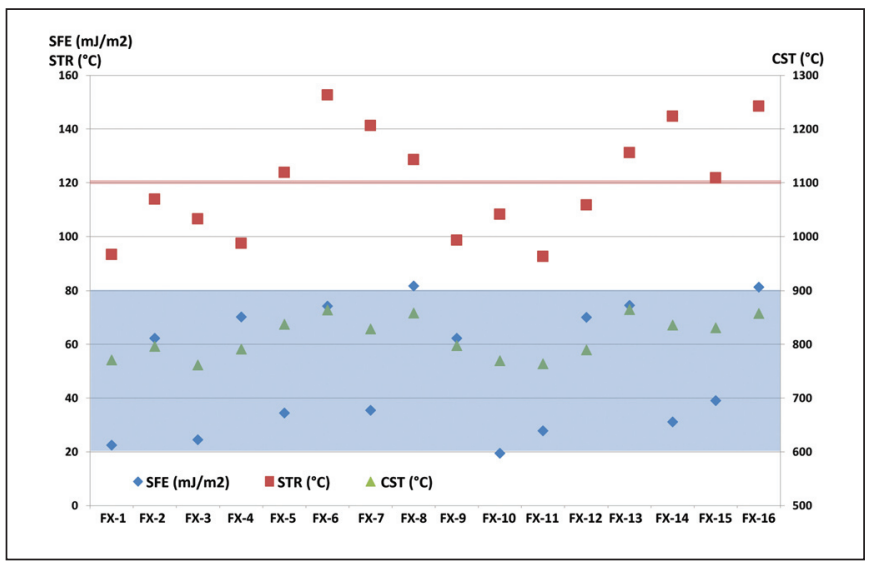

Fig. 3 - Calculated SFE, STR, and CST for the 16 design chemistries selected for further experimentation. The red line indicates the preferable maximum STR and the blue-shaded region indicates the target SFE range.

was noted as a primary problem and phosphorus was identified as a main factor. Although Ref. 15 was notable for its time, it lacked the advantage of modeling, electron microscopy, and identification/knowledge of modern theories about solidification cracking (Refs. 23-30). The more current studies on welding of HMS (Refs. 16-22, 31-36) have done well to apply modern techniques and to quantify the contribution of different alloys to cracking susceptibility. Relevant to the current work are the observations in Ref. 31 identifying that carbon and phosphorus are primary culprits of solidification cracking in HMSs while the presence of sulfur is apparently mitigated by the high Mn content and the quick formation of MnS, thus tying up sulfur.

The subject of this paper is the description of the welding development program for the new slurry pipeline application. After the literature review provided general ideas regarding weld chemistry, a computational thermodynamics approach was used to optimize the chemistry "on paper," after which experimental weld wires were made and tested to pick a champion. As previously mentioned, solidification cracking was a concern; however, it should be mentioned 
A

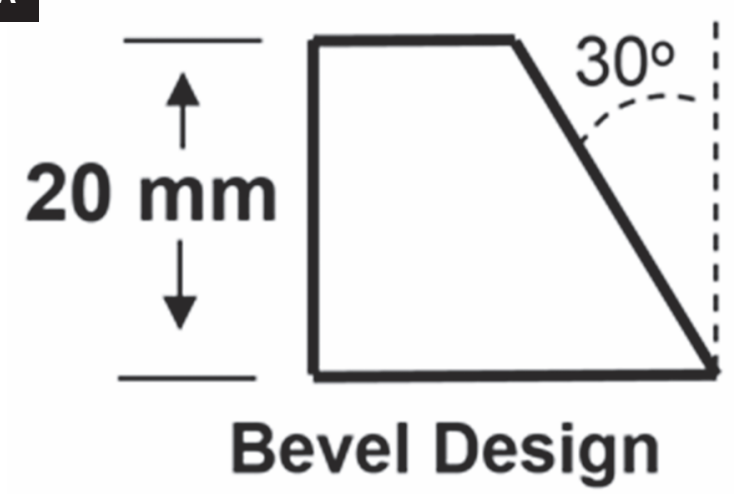

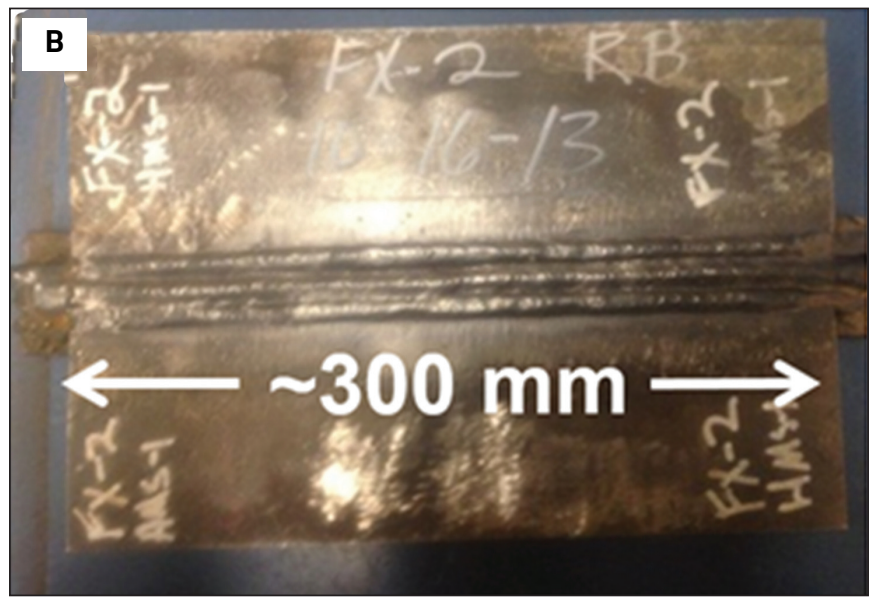

Fig. 4-A - Laboratory weld bevel design; B - plain view of one completed weldment.

that two of the primary factors in cracking susceptibility $(\mathrm{C}$ and $\mathrm{P}$ ) were not manipulated significantly to alter cracking behavior in the experimental wires. The experimental range for $C$ was controlled by the need to meet strength targets. And while measures were taken to minimize P (discussed below), P was not manipulated as an alloy variable in the experimental chemistries. Rather $\mathrm{P}$ was a byproduct of the wire making process, thus $\mathrm{P}$ was roughly similar amongst all wires tested.

\section{HMS Welding Consumable Development}

The first stage of the research was to develop a HMS weld (thus consumable wire) with an optimized chemistry. The steps included 1) selecting alloying elements to make a broad chemistry matrix; 2) calculating three key thermodynamic parameters using computational simulation; 3 ) investigating the effect of the alloying elements on the thermodynamic parameters using a design of experiments (DoE) approach; 4) using the DoE results to design an experimental matrix consisting of 16 weld wire chemistries for welding and testing; 5) manufacturing the weld wires; 6) performing lab tests using the 16 wires (strength, toughness, erosion resistance, and weldability); 7) and selecting a champion weld wire.

\section{Welding Consumable Alloying Elements Selection}

Key alloying elements that were selected for the computation exercise included $\mathrm{C}, \mathrm{Mn}, \mathrm{Si}, \mathrm{Cr}, \mathrm{Mo}, \mathrm{N}, \mathrm{Ni}$, and $\mathrm{Al}$. The anticipated effects of these alloys are explained as follows:

1) $\mathrm{Mn}$ is the primary element in HMS. It is a less costly replacement for $\mathrm{Ni}$ in stabilizing the austenite structure during cooling and deformation (Refs. 37, 38), and it has an important influence on the stacking fault energy (SFE) of the material system (Refs. 39, 40). It also provides a solid-solution strengthening effect to strengthen the matrix of the HMS (Ref.41).

2) $C$ serves as a solid-solution strengthener and austenite stabilizer (Ref. 42). Compared with the HMS base metal, the weld metal $C$ content is lowered $(<1 \%)$ to produce sufficient weldability and to avoid excessive carbide precipitation; however, it cannot be reduced too much or the strength targets will not be met. Despite the reduced carbon, the weld metal strength can be maintained by alloying with additional elements like Mo and N (Ref. 32).

3) Si can improve the weld pool fluidity during welding (Ref. 43). Since the molten HMS viscosity is higher compared with the conventional carbon steels, addition of Si can increase the ease of welding and help to reduce incomplete fusion defects. It also provides solid-solution strengthening, affects SFE and enhances strain hardening (Refs. 44, 45).

4) $\mathrm{Cr}$ is added to increase the corrosion resistance of the weld metal (Ref. 46). However, higher $\mathrm{Cr}$ content may lead to the formation of $\mathrm{Cr}$ carbides during weld cooling and/or reheating, which needs to be minimized to avoid toughness degradation.

5) The addition of Mo can provide significant solid-solution strengthening to the matrix. Moreover, it is a major element providing erosion and corrosion resistance, especially the resistance to pitting (Ref. 16).

6) $\mathrm{N}$ is a potent austenite stabilizer and solid-solution strengthener. It can be a replacement for $C$ and a small quantity of $\mathrm{N}$ addition can have a strong strengthening effect (Refs. 20, 47).

7) $\mathrm{Ni}$ is an austenite stabilizer and can improve the weld metal toughness (Ref. 48). However, higher Ni addition will result in a decrease of strength and increase in cost.

8) $\mathrm{Al}$ is known to be the very effective on increasing the SFE of HMS and therefore strongly influences the HMS deformation mechanisms (Refs. 49, 50).

\section{Thermodynamic Simulations and DoE}

High manganese steel alloys have a metastable austenite phase with a face-centered cubic (FCC) structure at room temperature. Upon straining, the metastable austenite phase can undergo dislocation gliding and a number of different phase transformations. These include micro-twins (FCC), $\varepsilon$-martensite (hexagonal close-packed lattice), and $\alpha^{\prime}$ martensite (body-centered tetragonal lattice), depending on specific steel chemistry, temperature, and/or strain rate. These transformation products are key in producing the unique properties of HMS.

To accelerate and optimize consumable development, thermodynamic simulation of potential alloy chemistries was performed, and then evaluated using a DoE approach. A 


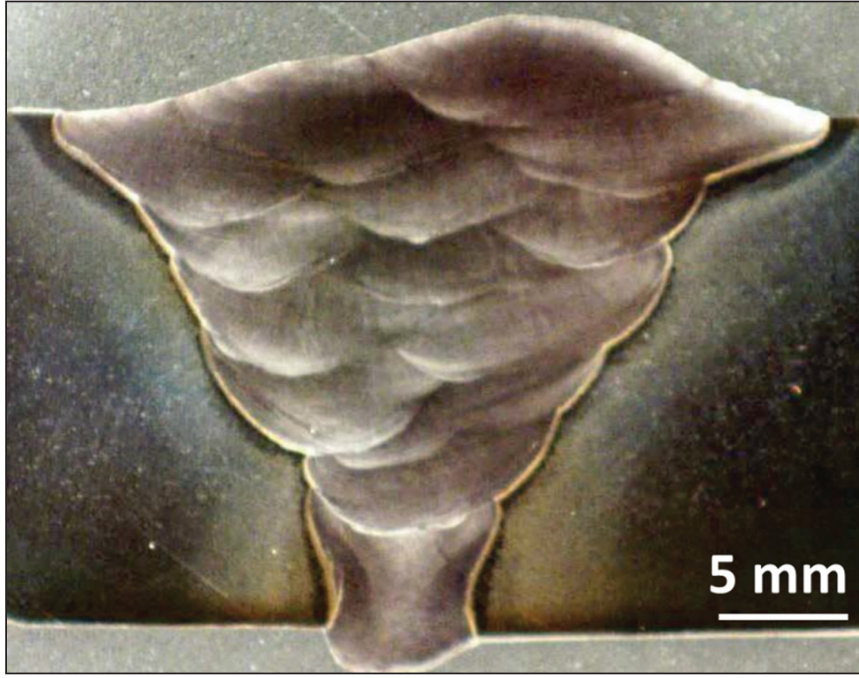

Fig. 5-A typical butt-joint weld macro.

full factorial matrix of eight elements and three concentrations were included (Table 1) for a total of 6561 consumable chemistry combinations. ThermoCalc software (Ref. 51) and the TCFE6 database (Ref. 52) were used to calculate three thermodynamic parameters: stacking fault energy (SFE) (Ref. 53), solidification temperature range (STR), and carbide solvus temperature (CST). These parameters were selected based on their expected influence on erosion resistance, weldability and toughness, respectively.

- SFE: Since the HMS girth weld will be exposed to erosive service, it is important to utilize a parameter in the computations that relates to erosion/wear resistance. SFE has been cited (Refs. 19, 54, 55) as a strong determinant of erosion resistance. Low SFE (less than $20 \mathrm{~mJ} / \mathrm{m}^{2}$ ) promotes strain-induced martensitic transformations. Intermediate SFE $\left(20 \sim 45 \mathrm{~mJ} / \mathrm{m}^{2}\right)$ promotes intense twinning, while higher values (greater than $45 \mathrm{~mJ} / \mathrm{m}^{2}$ ) promote plastic deformation by dislocation gliding (Ref. 22). It is believed that the best hardening rate (and therefore erosion resistance) can be achieved with mechanical twinning and gliding mechanisms during deformation (Refs. 56, 57). Therefore, a SFE range of $20-80 \mathrm{~mJ} / \mathrm{m}^{2}$ was selected as the target.

- STR: HMS alloys solidify as primary austenite, thus weld solidification cracking was considered to be a key technical challenge (Ref. 34). Alloys with lower equilibrium STR (between the liquidus and solidus temperatures) are known to have better resistance to weld solidification cracking (Refs. 28, 58). A target STR of $120^{\circ} \mathrm{C}$ or less was considered preferable (with less than $100^{\circ} \mathrm{C}$ considered optimal) for this alloy system.

- CST: Another technical challenge for HMS welds is the precipitation and growth of coarse carbides at grain boundaries, which can greatly diminish fracture toughness. Carbides will only precipitate during weld solidification if they are thermodynamically stable at high enough temperatures to allow the necessary diffusion of carbon. Therefore, alloys with a low CST were preferred.

After the calculation of SFE, STR, and CST was completed for the matrix of 6561 chemistries, MiniTab software was used to analyze the influence of each alloying element on

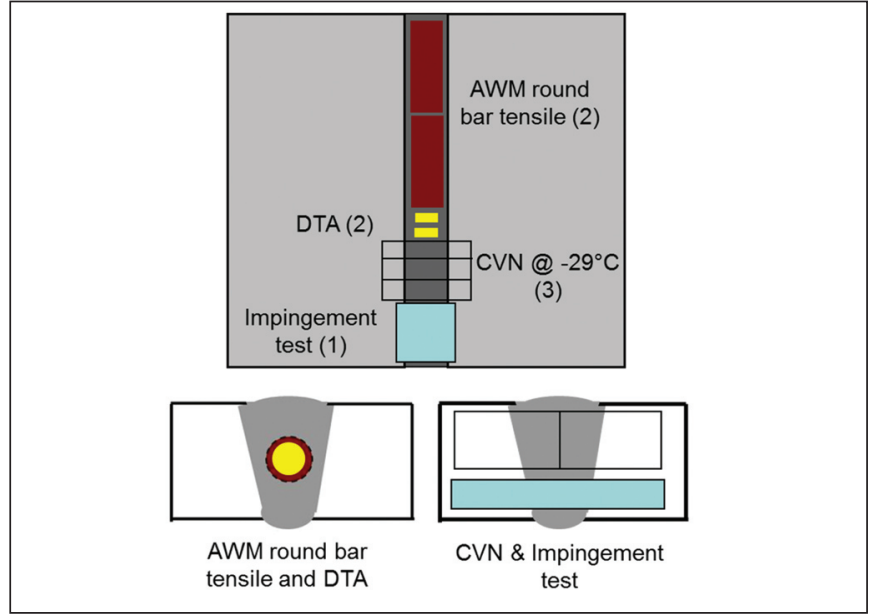

Fig. 6 - Extraction of tensile, CVN, jet impingement, and DTA testing coupons from the test welds (number in parenthesis indicates the quantity of the test coupons).

Table 1-Selection of Key Elements and Concentrations Evaluated Using Thermodynamic Simulation

\begin{tabular}{cccc} 
& Min & Mid & Max \\
\hline $\mathrm{C}$ & 0.4 & 0.6 & 0.8 \\
$\mathrm{Mn}$ & 18 & 21 & 24 \\
$\mathrm{Si}$ & 0.4 & 0.7 & 1 \\
$\mathrm{Cr}$ & 0 & 3 & 6 \\
$\mathrm{Mo}$ & 0 & 2 & 4 \\
$\mathrm{~N}$ & 0 & 0.03 & 0.06 \\
$\mathrm{Ni}$ & 0 & 2.5 & 5 \\
$\mathrm{Al}$ & 0 & 0.5 & 1 \\
\hline
\end{tabular}

these thermodynamic parameters. Figure $2 \mathrm{~A}-\mathrm{C}$ show the main effect plots for each parameter. Some alloying elements demonstrated a strong effect (indicated by a high slope), while others showed negligible effect (indicated by a flat slope). $\mathrm{Al}, \mathrm{Si}, \mathrm{N}$, and, most interestingly, $\mathrm{Mn}$ were shown to have only minor effects on SFE, STR, and CST within the composition limits that were studied. Of the remaining four elements, only $C$ was found to impact all three parameters. Rather than fully accept the ThermoCalc results, some additional considerations were used to help select elements for the experimental design studies. The computational work found little influence of $\mathrm{N}$ on key parameters. This combined with knowledge that $\mathrm{N}$ content is difficult to control in arc welds motivated the decision not to pursue purposeful $\mathrm{N}$ additions. Prior investigations during base metal development found that $3 \% \mathrm{Cr}$ provides good corrosion resistance without dominant carbide precipitation; therefore, $3 \%$ $\mathrm{Cr}$ was selected as the baseline value for the experimental consumables. Previous consumable development work by the authors had found that $\mathrm{Si}$ contents in the range of 0.4$0.6 \%$ were effective in enhancing weld pool fluidity, so $0.4 \%$ was selected for the wire chemistries. Mn content was selected based on a starting point equaling that of the base pipe (18\%), yet an additional sensitivity of $21 \%$ was explored to err on the side of higher stacking fault energy and 


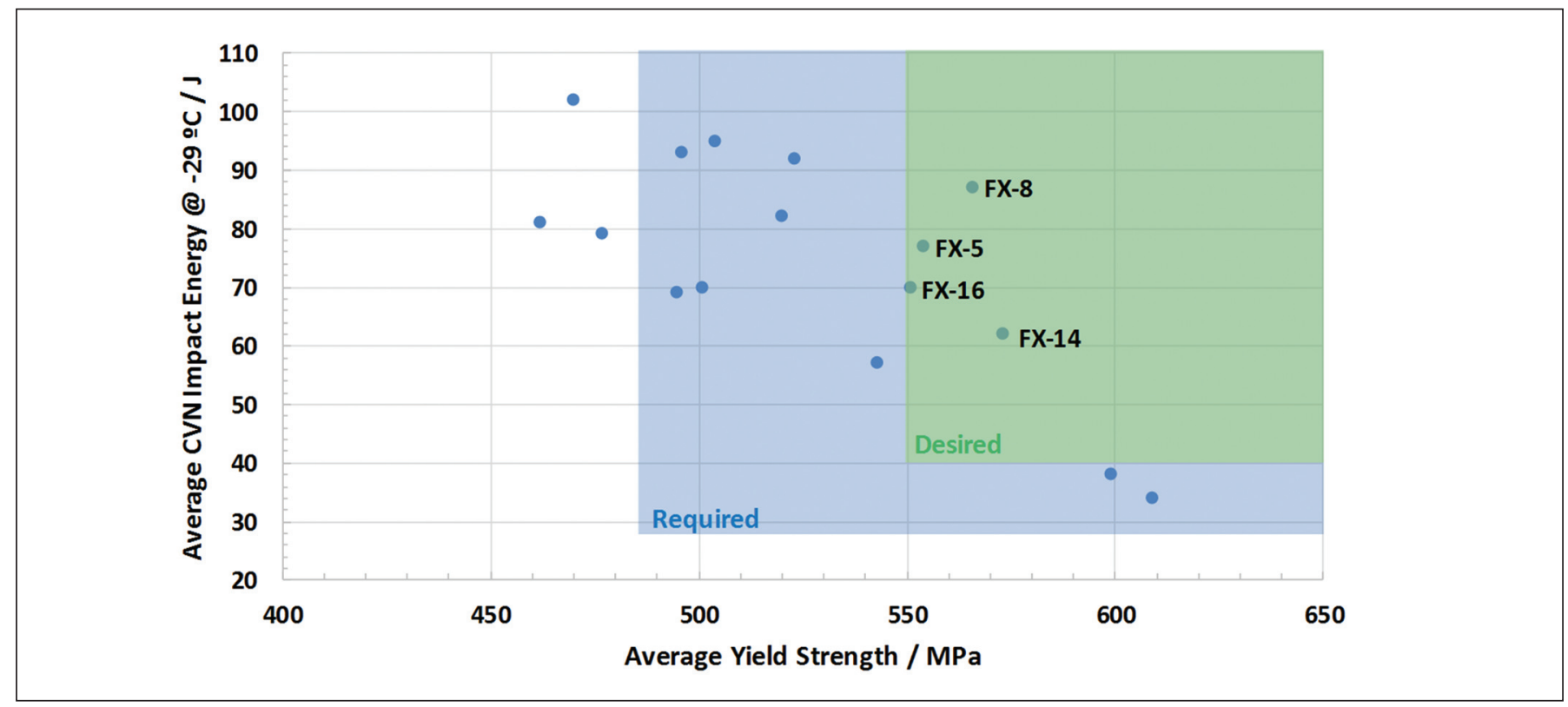

Fig. 7-Plot of average yield strength and CVN toughness for all test welds.

stabilization of austenite. This was partly motivated to offset the decision to limit carbon for toughness and weldability concerns. The experimental consumables therefore contained variations of $\mathrm{C}, \mathrm{Mn}, \mathrm{Mo}$, and $\mathrm{Ni}$. $\mathrm{Al}, \mathrm{N}, \mathrm{Cr}$, and $\mathrm{Si}$ were held constant.

A matrix of experimental chemistries was designed according to the above information and with regard to the target criteria for SFE, STR, and CST. Selecting two concentrations from each of the four variable elements generated a full factorial matrix of 16 chemistries, which was considered manageable for the experimental phase. The final selection of nominal wire compositions (designated as FX-1 to FX-16), along with their predicted SFE, STR, and
CST values, are listed in Table 2 ( $\mathrm{Al}$ and $\mathrm{N}$ additions were $0 \%$ in all cases).

The plot in Fig. 3 compares these predicted values against the established criteria. These data demonstrate there was some difficulty in fully achieving the desired thermodynamic criteria. While nearly all of the alloys met the SFE criteria, only half met the STR criteria. The $750^{\circ}-900^{\circ} \mathrm{C}$ range of CST's predicted in these alloys are near the median value of the CST predicted across the original $3^{8}$ matrix of simulated alloys. It was therefore anticipated that welding procedure controls may be necessary to prevent solidification cracking and to limit carbide precipitation.

Table 2 - Nominal Alloy Compositions and the SFE, STR, CST Predicted by Thermodynamic Simulation

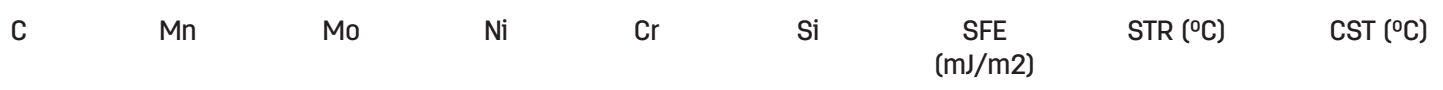

\begin{tabular}{|c|c|c|c|c|c|c|c|c|c|}
\hline FX-1 & 0.4 & 18 & 2 & 0 & 3 & 0.4 & 22.55 & 93.3 & 770.7 \\
\hline FX-2 & 0.4 & 18 & 4 & 5 & 3 & 0.4 & 62.29 & 113.8 & 796.4 \\
\hline FX-3 & 0.4 & 21 & 4 & 0 & 3 & 0.4 & 24.52 & 106.6 & 761.7 \\
\hline FX-4 & 0.4 & 21 & 2 & 5 & 3 & 0.4 & 70.22 & 97.4 & 791.1 \\
\hline FX-6 & 0.6 & 18 & 4 & 5 & 3 & 0.4 & 74.28 & 152.6 & 863.6 \\
\hline FX-7 & 0.6 & 21 & 4 & 0 & 3 & 0.4 & 35.51 & 141.2 & 828.8 \\
\hline FX-8 & 0.6 & 21 & 2 & 5 & 3 & 0.4 & 81.72 & 128.6 & 858.3 \\
\hline FX-11 & 0.4 & 21 & 2 & 0 & 3 & 0.4 & 27.89 & 92.5 & 763.5 \\
\hline FX-12 & 0.4 & 21 & 4 & 5 & 3 & 0.4 & 70.01 & 111.7 & 789.4 \\
\hline FX-13 & 0.6 & 18 & 2 & 5 & 3 & 0.4 & 74.50 & 131.2 & 864.4 \\
\hline FX-14 & 0.6 & 18 & 4 & 0 & 3 & 0.4 & 31.18 & 144.7 & 836.1 \\
\hline FX-15 & 0.6 & 21 & 2 & 0 & 3 & 0.4 & 39.07 & 121.9 & 830.4 \\
\hline FX-16 & 0.6 & 21 & 4 & 5 & 3 & 0.4 & 81.27 & 148.5 & 857.2 \\
\hline
\end{tabular}




\section{A}

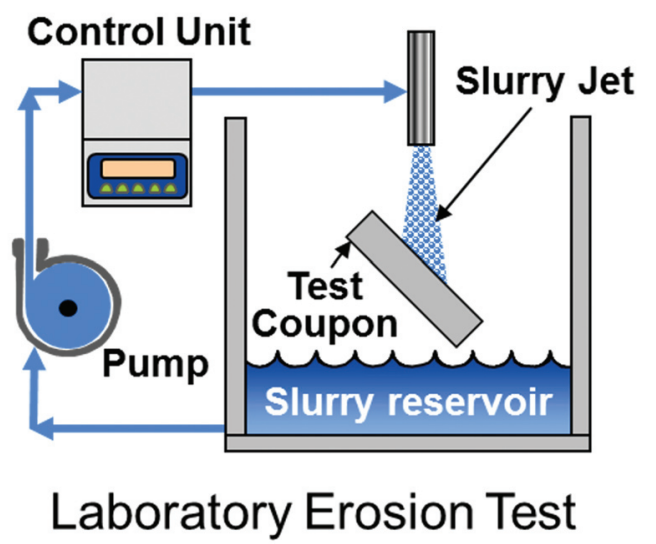

\section{B}

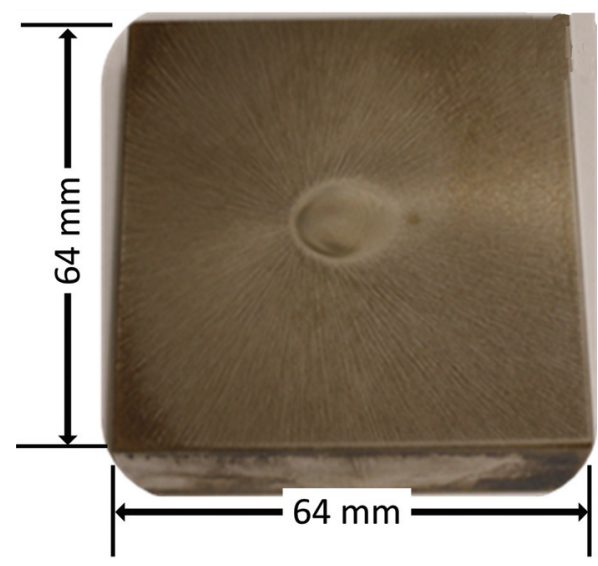

Fig. $8-A-$ Schematic of the jet impingement test; $B-a$ coupon after testing.

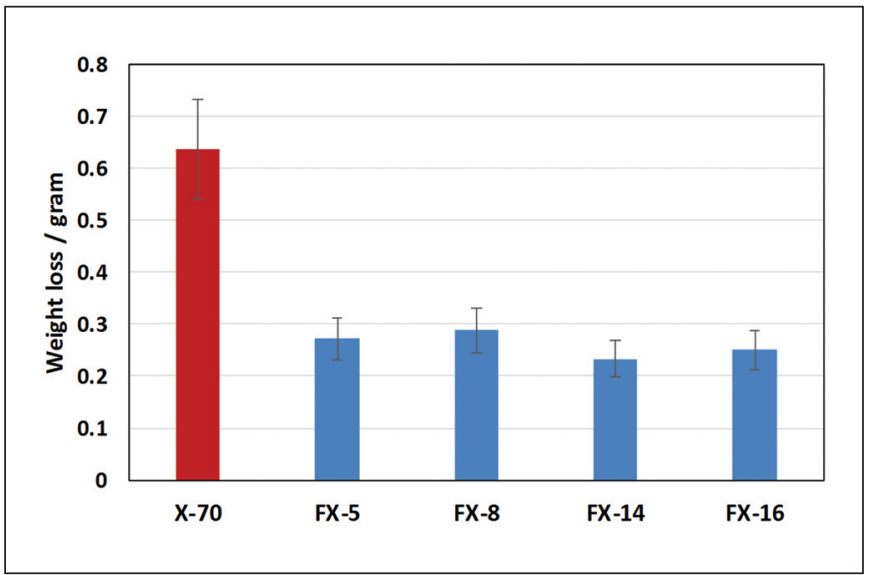

Fig. 9 - Jet impingement test results for the X70 and the four welding consumable alloys.

\section{Laboratory Welding}

The designed experimental consumable alloys (FX-1 FX16) were manufactured as 1.2-mm-diameter cored wires (for metal cored arc welding (MCAW)) by Pohang Special Welding Co. Ltd., a subsidiary of POSCO. For each wire, a butt-joint weld was made from which mechanical and metallurgical test specimens were extracted. The HMS base plates were of the type used for pipe manufacture. The dimensions were $20 \mathrm{~mm}$ thick, $100 \mathrm{~mm}$ wide, and $300 \mathrm{~mm}$ long. The weld bevel was a 60-deg geometry (Fig. 4A) as this configuration was anticipated to reduce weld bead depth-to-width ratio, limit residual stresses (compared to typical narrow groove pipeline welds), and thus reduce the tendency for weld solidification cracking.

Welding was performed in the flat $(1 G)$ position. $80 \%$ $\mathrm{Ar} / 20 \% \mathrm{CO}_{2}$ shielding gas was used at a flow rate of $20 \mathrm{~L} / \mathrm{min}$. The shielding gas with the flow rate can provide a combination of good arc stability, weld pool fluidity, and welding speed. Welding heat input was maintained at $1 \mathrm{~kJ} / \mathrm{mm}$ for all passes and all welds. This heat input was chosen to minimize carbide precipitation in the weld metal and heat-affected zone (HAZ) in order to prevent the degradation of fracture toughness. One completed weldment can be seen in Fig. 4B and an example weld macro is shown in Fig. 5.

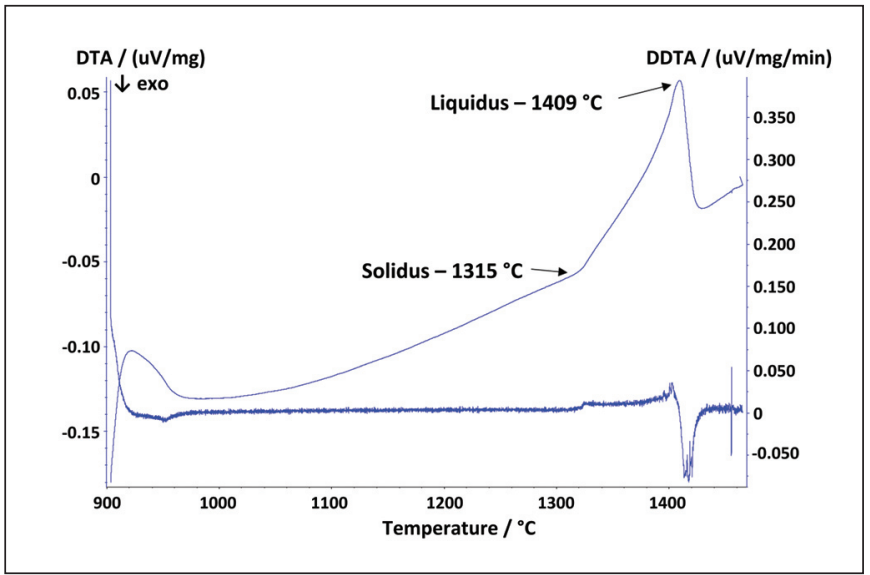

Fig. $10-$ A typical DTA output plot with derivative curve to determine solidus and liquidus (FX-5).

\section{Mechanical Testing, Erosion, and Weldability Evaluation}

The 16 welds were subjected to all-weld-metal (AWM) tensile, Charpy V-notch (CVN) toughness, erosion, and differential thermal analysis (DTA) tests. Test sample layout is shown in Fig. 6. Two AWM round bar tensile coupons were cut from the midsection of the weld, away from the fusion boundary and root pass, to limit base metal dilution effects. The tensile coupons were of the round bar geometry with a diameter of $6.35 \mathrm{~mm}$ and a gauge length of $25.4 \mathrm{~mm}$ as per Ref. 59. Tensile testing was conducted at room temperature using an MTS tensile testing system with 55,000-lb load capacity. The CVN coupons were full-size $(10 \mathrm{~mm} \times 10 \mathrm{~mm} \times$ $100 \mathrm{~mm}$ ), and the notch was cut at the weld centerline (WCL) in the through-thickness direction. The CVN tests were performed per Ref. 60 at $-29^{\circ} \mathrm{C}$ using a $400 \mathrm{ft}-\mathrm{lb}(540$ J) Tinius Olsen Charpy testing machine.

The tensile and CVN results are summarized in Table 3 and plotted in Fig. 7. This figure includes two shaded regions. The broad region is positioned according to the specified minimums of the design code (Ref. 61); $485 \mathrm{MPa}$ and 27 $\mathrm{J}$ for yield strength and CVN toughness, respectively. The smaller shaded region was selected as the experimental target. The narrower target was motivated by the expectation 


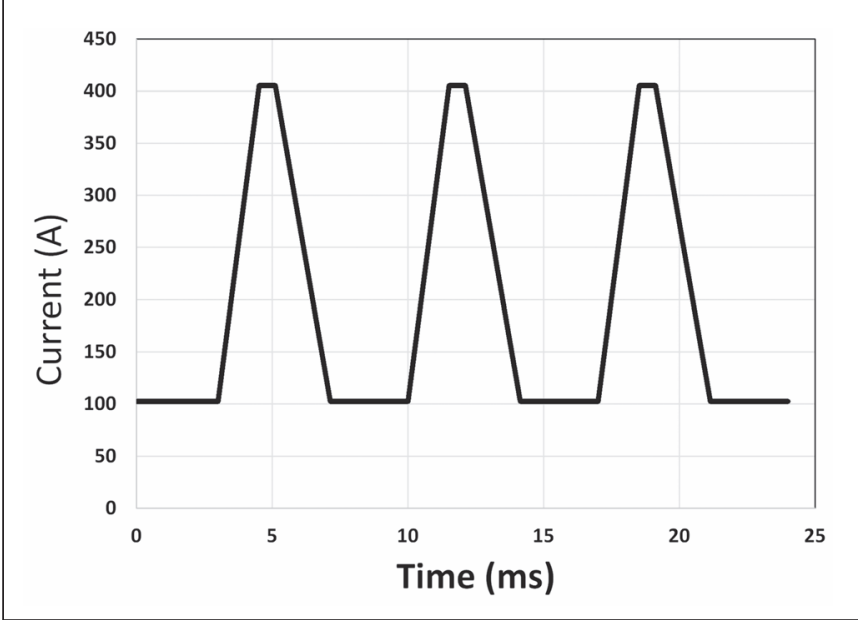

Fig. $11-$ Pulsed spray welding current waveform.

that production welding would bring a higher degree of statistical variation, thus a "buffer" was thought to be useful during the experimental phase. Thirteen of the 16 wires passed the code minimum requirements. Four wires, FX-5, FX-8, FX-14, and FX-16, were found to achieve the more re-

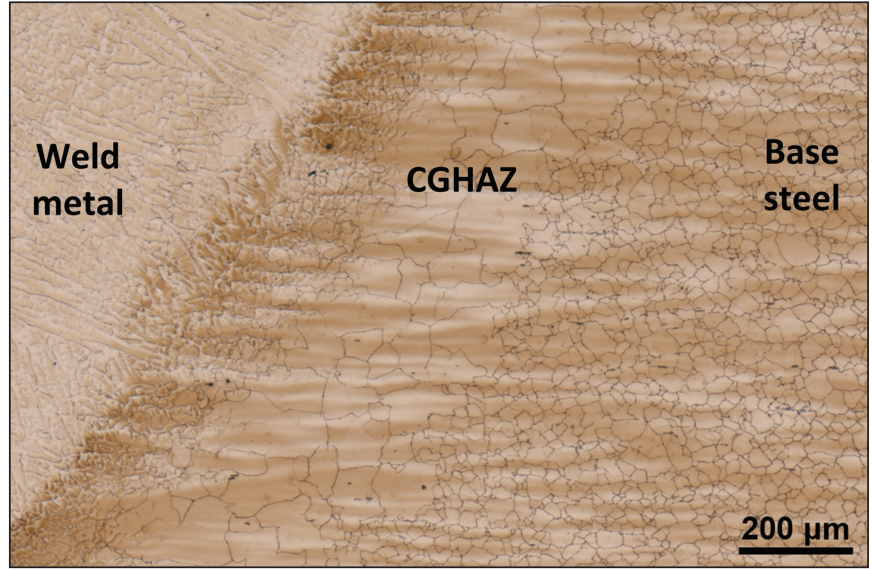

Fig. 12 - Microstructure of the FX-5 weldment, showing weld metal, coarse-grained heat-affected zone (CGHAZ), and base HMS steel (from left to right).

strictive targets. An inverse relationship between strength and toughness is noted by the decreasing slope of the data (high strength correlates to lower toughness). FX-5, FX-8, FX-14, and FX-16 were subjected to jet impingement and DTA testing to evaluate the erosion resistance and the solid-

Table 3 - Mechanical Properties of FX-1 FX-16

\begin{tabular}{|c|c|c|c|}
\hline Alloy & Avg Yield Strength (MPa) & Avg Tensile Strength (MPa) & $\operatorname{Avg} \mathrm{CVN}_{-29^{\circ} \mathrm{C}}(\mathrm{J})$ \\
\hline FX-1 & 462 & 824 & 81 \\
\hline FX-2 & 501 & 764 & 70 \\
\hline FX-3 & 543 & 847 & 57 \\
\hline FX-5 & 554 & 908 & 77 \\
\hline FX-6 & 599 & 865 & 38 \\
\hline FX-7 & 609 & 888 & 34 \\
\hline FX-10 & 495 & 835 & 69 \\
\hline FX-11 & 477 & 801 & 79 \\
\hline FX-12 & 496 & 745 & 93 \\
\hline FX-13 & 523 & 784 & 92 \\
\hline FX-14 & 573 & 915 & 62 \\
\hline FX-15 & 520 & 869 & 82 \\
\hline
\end{tabular}

Table 4-Temperature Schedule of the DTA Test

Temperature $\left({ }^{\circ} \mathrm{C}\right)$

Heating or Cooling Rate $\left({ }^{\circ} \mathrm{C} / \mathrm{min}\right)$

Time (min)

$\begin{array}{lr}\text { Heat to } & 900 \\ \text { Isothermal Hold } & 900 \\ \text { Heat to } & 1480 \\ \text { Isothermal Hold } & 1480 \\ \text { Cool to } & 900 \\ \text { Isothermal Hold } & 900 \\ \text { Heat to } & 1480 \\ \text { Isothermal Hold } & 1480 \\ \text { Cool to } & 900 \\ \text { Isothermal Hold } & 900\end{array}$

$\begin{array}{cc}50 & - \\ - & 1 \\ 10 & - \\ - & 1 \\ 10 & - \\ - & 1 \\ 10 & - \\ - & 1 \\ 10 & - \\ - & 1\end{array}$



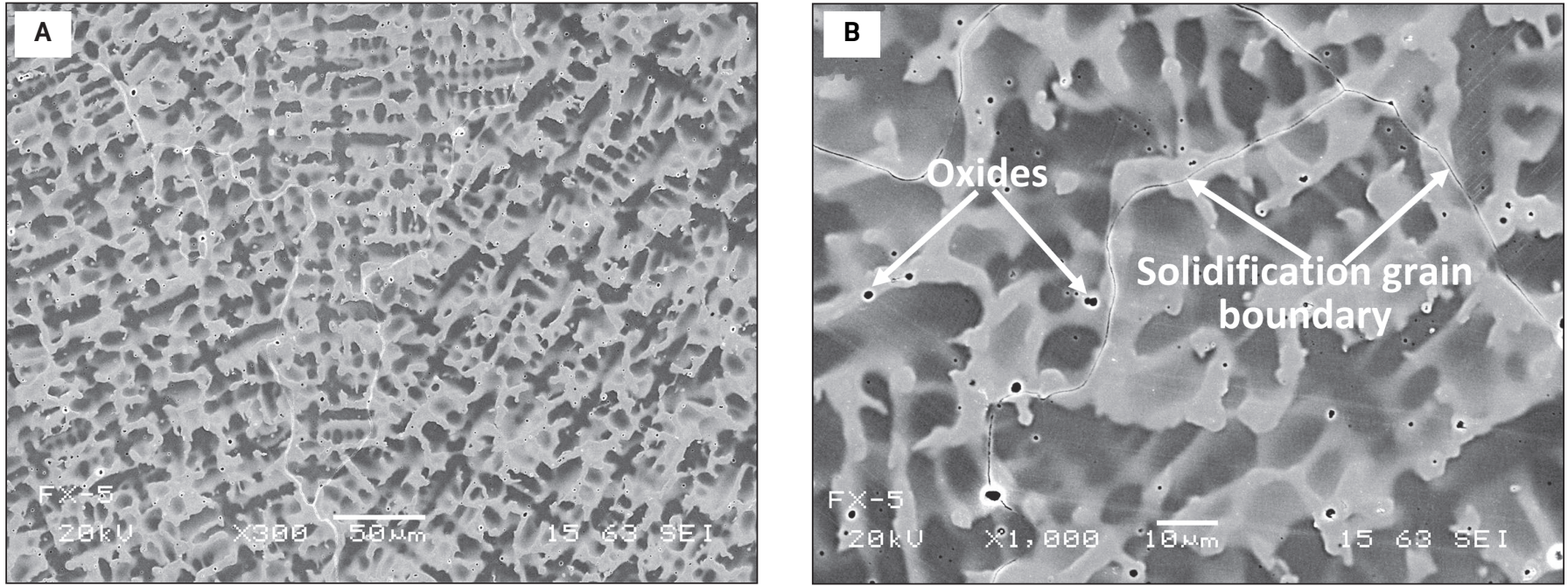

Fig. 13 - FX-5 weld metal SEM images showing: A - Dendritic austenite at low magnification; B - oxides at higher magnification.

ification cracking susceptibility, respectively.

A schematic of the jet impingement test is shown in Fig. 8A. A flat coupon $(64 \mathrm{~mm} \times 64 \mathrm{~mm} \times 12 \mathrm{~mm})$ was extracted from the root pass area of the weldment for testing. The root region was selected because in the actual field application, this material is the first to be subjected to slurry erosion and it plays an important role in girth weld performance. In the test, a high velocity jet of water and sand mixture continuously impinges the weld at a 45-deg angle for a prescribed rate and duration. An erosion dimple (i.e., material loss) forms on the weld as shown in Fig. 8B. The coupon mass before and after the test was measured to determine weight loss as a measure of erosion resistance. The smaller the loss, the better the erosion resistance. Although the jet impingement test is not a perfect replication of slurry pipeline conditions, it can provide an indication of relative performance. Figure 9 shows the jet impingement results for the four alloys along with the conventional X-70 pipeline steel. It can be seen that the mass loss of the four alloys is comparable and about $36 \%-45 \%$ of the X-70 steel. The results confirm that these four experimental alloys (weld wires) have significantly better erosion resistance than X-70.

To explore solidification cracking tendency, DTA testing was performed to measure the STR for the four alloys. DTA testing is a strong indicator of cracking susceptibility, as the measured STR correlates with the span of the weld pool mushy zone during solidification (Ref. 62). Generally speaking, if the STR is less than $\sim 100^{\circ} \mathrm{C}$, the alloy usually exhibits good cracking resistance. A higher STR represents higher susceptibility (Ref. 30) and a need for careful weld procedure development.

Two DTA coupons of $5 \mathrm{~mm}$ in diameter and $3 \mathrm{~mm}$ in length were cut from the midsection of each weld (Fig. 6). DTA testing was performed using a Netzsch STA 409 differential thermal analyzer. Prior to testing, the system was calibrated using

Table 5 - DTA Test Results

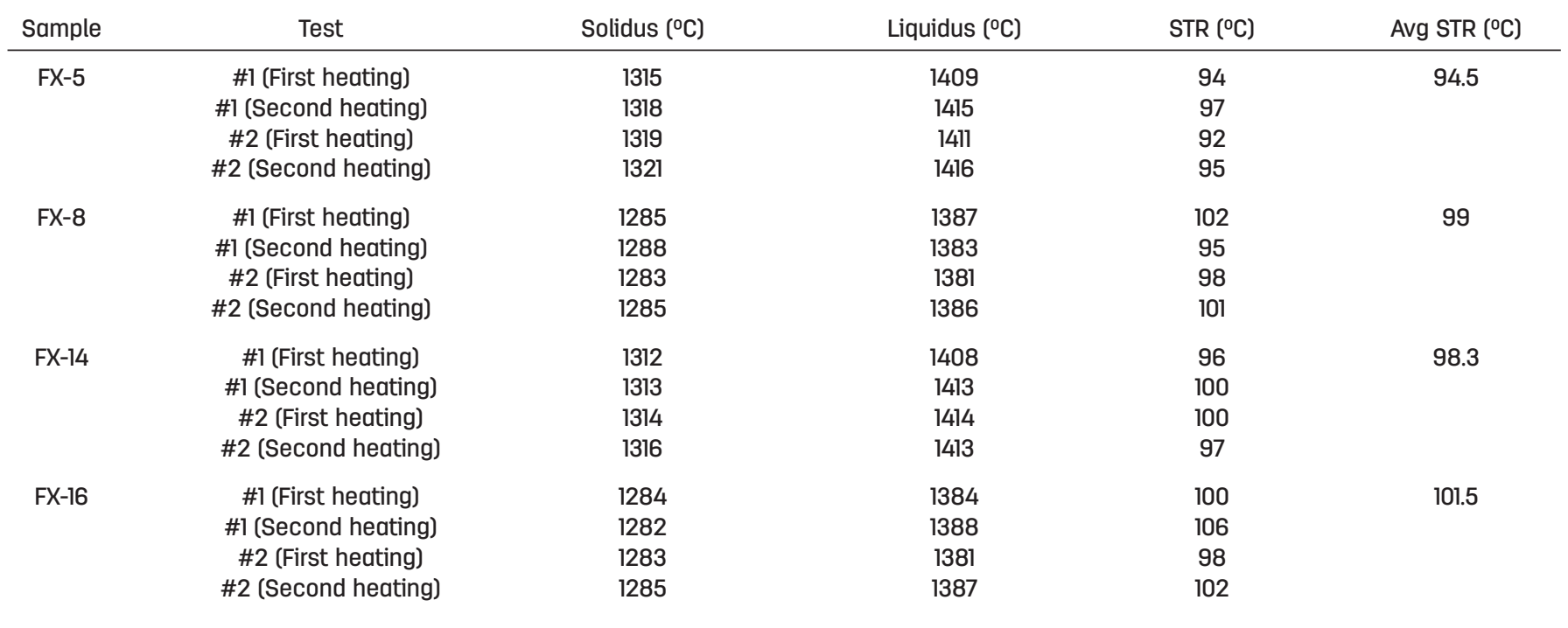




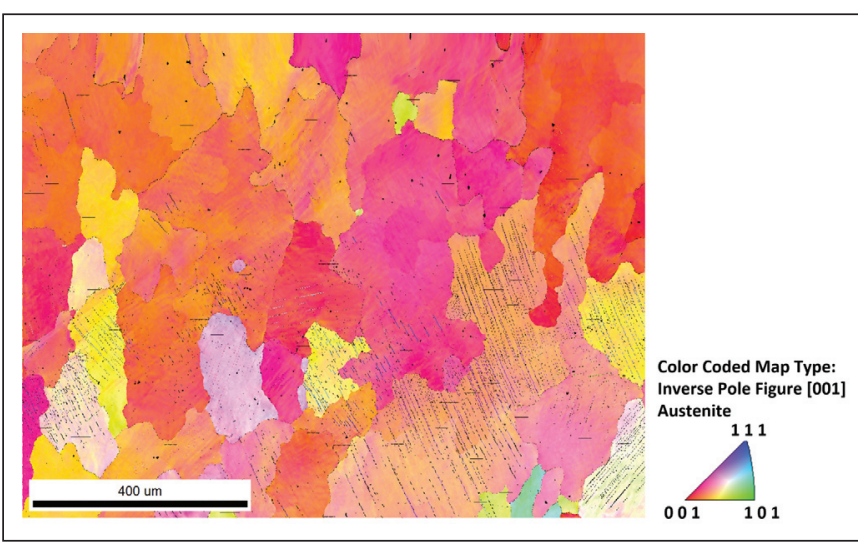

Fig. 14 - EBSD map of the FX-5 weld metal.

pure $\mathrm{Ni}, \mathrm{Co}$ and $\mathrm{Au}$. Two coupons from each alloy were heated and cooled under pure argon. The temperature schedule of the DTA test is shown in Table 4. Each coupon was subjected to two heating segments from $900^{\circ}$ to $1480^{\circ} \mathrm{C}$, during which the solidus and liquidus temperatures were identified from the thermal curve as the deviation points (Fig. 10). STR was determined as the difference between the liquidus and solidus temperatures. The DTA results for the four alloys are summarized in Table 5. The data shows excellent reproducibility between the four measurements of liquidus and solidus temperatures with individual measurements typically within $1^{\circ}$ to $5^{\circ} \mathrm{C}$ of each other. Of the four alloys, FX-5, FX-8, and FX-14 have STRs less than $100^{\circ} \mathrm{C}$. FX-5, having the lowest STR of $94.5^{\circ} \mathrm{C}$, indicating the best resistance to solidification cracking.

The mechanical, erosion, and DTA test results were taken into account to select the best consumable wire. Among the four alloys, FX-5 and FX-8 have better low temperature toughness compared with FX-14 and FX-16, while maintaining comparable erosion resistance. Between FX-5 and FX-8, FX-5 exhibited the lower STR and therefore better resistance to weld solidification cracking. Because FX-5 had lower Mn and $\mathrm{Ni}$ additions than $\mathrm{FX}-8$, it also demonstrated better weld pool fluidity during lab welding. FX-5 was therefore selected as the champion wire for joining the HMS pipelines.

\section{Welding Procedure Development and Qualification}

For reasons associated with using a new pipeline material (i.e., risk) and desires for easy installation and maintenance, it was decided that a first commercial application of the HMS pipe would be accomplished using double-length pipe joints with flanged connections at each end. The flanged connections allow easy disconnection, inspection, repair, and replacement. The double joints were to be fabricated in a shop environment by butt-joint welding, thus a need existed to develop a 1G-rolled welding procedure. The following summarizes the weld procedure development work and the procedural details are shown in Table 6 . A range of welding parameters was selected based on our welding knowledge and experience, and then narrowed down using trial and error welding runs. The development work was conducted using an external pipe welding system (this equipment was selected because it was anticipated that a $5 \mathrm{G}$ procedure would be needed in the future).

Two weld metal transfer modes, short circuit and pulsed spray, were used for the root and fill passes, respectively. The lower current and heat input of the short circuit mode enabled root welding without the use of backing to secure the molten weld pool. Adjustments were made to travel speed and torch oscillation to mitigate the common problems of pool drop out, inconsistent root bead profile, and incomplete penetration.

Due to the level of $C$ and $\mathrm{Mn}$ in the developed HMS weld metal, as compared to typical C-Mn steel welds, it is challenging to apply traditional welding techniques. HMS weld metal is substantially more viscous when molten than conventional low-carbon steel weld metals. The increased viscosity can result in incomplete fusion defects at weld toes located between the weld bead edges and the base metal.

Moreover, the toughness of the HMS base metal is sensitive to thermal cycles from welding. As a result, if the heat input during welding is too high, the HMS metal HAZ can have an unacceptable level of toughness. Also, as mentioned previously, HMS weld metal solidifies as primary austenite and is therefore prone to solidification cracking if welding is not properly controlled. In order to overcome these challenges, a custom pulsed waveform (as shown in Fig.11) was developed

Table 6 - Qualified Pipe Girth Welding Procedures for FX-5

Process
Bevel
Welding position
Shielding gas
Shielding gas flow rate
Preheat temperature,
Interpass temperatur

Current and polarity
Transfer mode
Voltage
Current
Travel speed
Wire feed speed
Heat input

Process

Welding position

Shielding gas

Shielding gas flow rate

Preheat temperature, min.

Interpass temperature
Metal cored arc welding (MCAW)

60-deg included angle, 4- $\mathrm{mm}$ root opening

IG

$80 \% \mathrm{Ar}, 20 \% \mathrm{CO}_{2}$

$24 \mathrm{~L} / \mathrm{min}$

$100^{\circ} \mathrm{C}$

$100^{\circ} \mathrm{C}$ min. $260^{\circ} \mathrm{C}$ max.

\section{Root pass}

Direct current electrode positive

Short circuit

20-22 V

150-165 A

$19.6-21.3 \mathrm{~cm} / \mathrm{min}$

$586.7 \mathrm{~cm} / \mathrm{min}$

$0.91-1.02 \mathrm{~kJ} / \mathrm{mm}$
Fill passes

Direct current electrode positive Pulsed spray

23.9-31.2 V

207-265 A

$46.2-58.4 \mathrm{~cm} / \mathrm{min}$

$1005.8-1120.1 \mathrm{~cm} / \mathrm{min}$

$0.59-0.94 \mathrm{~kJ} / \mathrm{mm}$ 

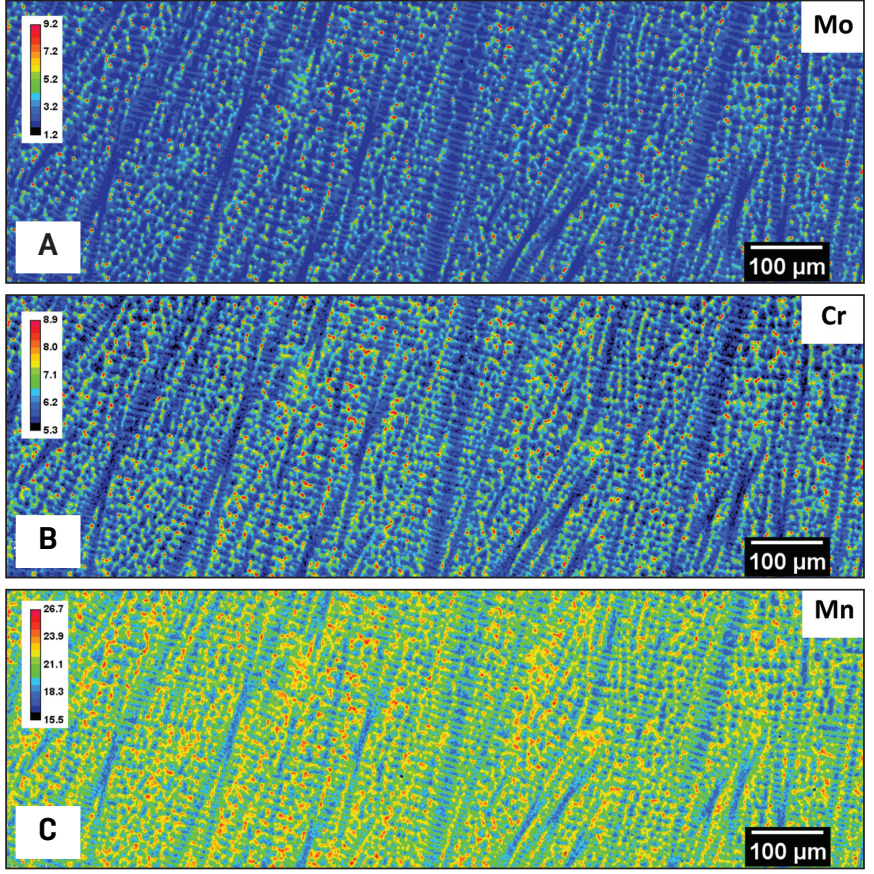

Fig. 15 - Elemental maps for Mo, Cr, and $\mathrm{Mn}$ in the FX-5 weld metal. A - Mo; B $-\mathrm{Cr} ; \mathrm{C}-\mathrm{Mn}$.

for the FX-5 consumable. Welding current pulse parameters such as background current, peak current, current rise slope, current drop slope, and pulsing frequency were optimized through welding trials to produce a pulsed spray transfer with the best combination of welding productivity and weld quality. The custom pulsed waveform provides weld pool fluidity and arc stability that cannot be otherwise achieved with this weld metal.

In addition to the pulsed waveform described previously, weld joint geometry was controlled to enable successful development and qualification of the girth welding procedure. Solidification cracking is dependent on the magnitude and location of weld residual stresses that develop during weld solidification. The use of specific weld bevel geometries can lead to more favorable weld residual stresses and improved

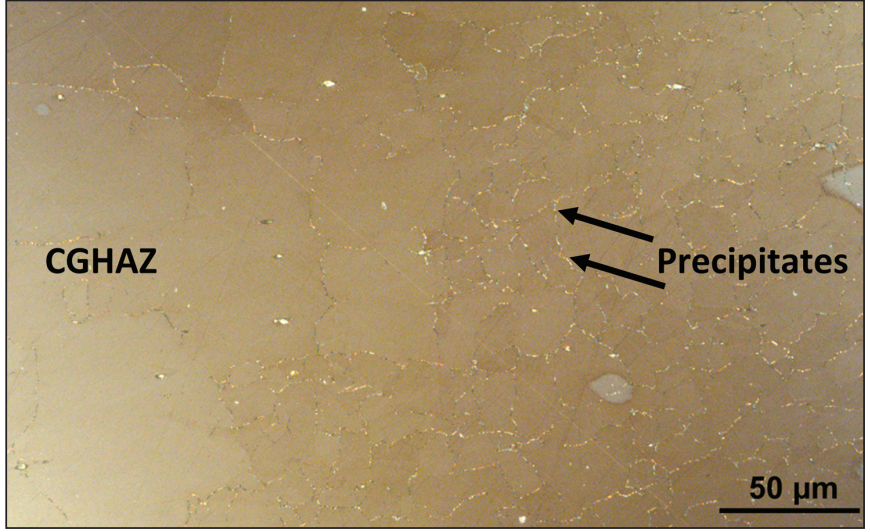

Fig. 16 - Precipitates adjacent to the CGHAZ restricting the grain growth.

resistance to solidification cracking. Open bevels with larger included angles result in weld beads with lower depth-towidth ratios, which reduces solidification cracking susceptibility compared to narrow bevels with smaller included angles and larger thermally induced stresses. As a result of solidification cracking that occurred in the early stages of procedure development, the bevel angle was increased to $30 \mathrm{deg}$ (60 deg included) to improve cracking resistance.

The welding travel speed, current, and voltage were controlled to keep the heat input below about $1 \mathrm{~kJ} / \mathrm{mm}$ to minimize carbide precipitation in the weld metal and in the base metal HAZ. Early studies indicated that excessive heat input can significantly reduce HMS base metal HAZ toughness to below acceptable levels.

Cross-weld tensile, CVN, and guided side bend tests were performed to qualify the developed welding procedure for FX-5 per the project specification and ASME Section IX (Ref. 63). The test results are summarized in Table 7 . The girth weld property requirements were based on a typical API X70 grade slurry pipeline steel to ensure the weld provides the required strength, toughness, and quality for the slurry pipe application. The FX-5 weld met all the requirements. It can be seen that the tensile strength and elongation are much higher than the requirement. CVN testing was con-

Table 7 - Summary of ASME Section IX Test Results on FX-5 Girth Weld Produced during Welding Procedure Qualification

\begin{tabular}{|c|c|c|c|}
\hline Test Type & Property & Requirement & FX-5 Weld Result \\
\hline Cross-Weld Tensile & $\begin{array}{l}\text { Yield Strength } \\
\text { Ultimate Tensile Strength } \\
\text { Tensile Elongation }\end{array}$ & $\begin{array}{l}>485 \mathrm{MPa} \\
>570 \mathrm{MPa} \\
\quad>16 \%\end{array}$ & $\begin{array}{c}554 \mathrm{MPa} \\
908 \mathrm{MPa} \\
51.5 \%\end{array}$ \\
\hline CVN & 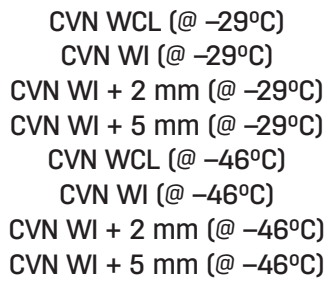 & $\begin{array}{l}>27 \mathrm{~J} \\
>27 \mathrm{~J} \\
>27 \mathrm{~J} \\
>27 \mathrm{~J} \\
>27 \mathrm{~J} \\
>27 \mathrm{~J} \\
>27 \mathrm{~J} \\
>27 \mathrm{~J}\end{array}$ & $\begin{array}{l}\text { Avg: } 66.4 \mathrm{~J} \\
\text { Avg: } 71.9 \mathrm{~J} \\
\text { Avg: } 71.3 \mathrm{~J} \\
\text { Avg: } 90.4 \mathrm{~J} \\
\text { Avg: } 70.1 \mathrm{~J} \\
\text { Avg: } 65.5 \mathrm{~J} \\
\text { Avg: } 49.8 \mathrm{~J} \\
\text { Avg: } 70.5 \mathrm{~J}\end{array}$ \\
\hline $\begin{array}{l}\text { Guided Side } \\
\text { Bend Tests }\end{array}$ & & $\begin{array}{l}\text { No open discontinuity } \\
\text { greater than } 3 \mathrm{~mm}\end{array}$ & $\begin{array}{c}4 \text { out of } 4 \\
\text { acceptable }\end{array}$ \\
\hline
\end{tabular}



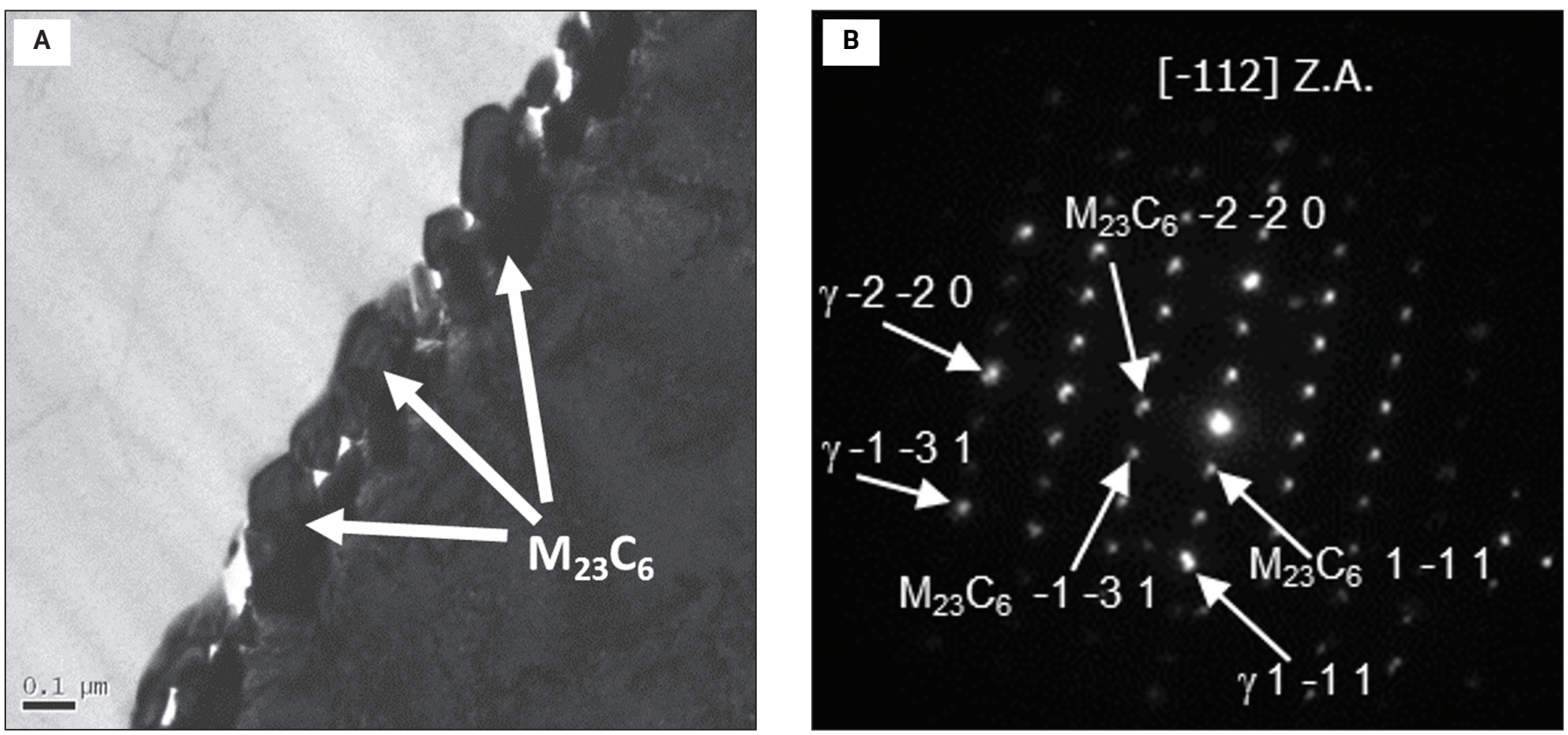

Fig. $17-A-T E M$ bright-field image showing the precipitates decorating the grain boundary; B - SADP along the grain boundary.

ducted at the WCL, weld interface (WI), WI $+2 \mathrm{~mm}$, and WI $+5 \mathrm{~mm}$ to assess the toughness of those regions at $-29^{\circ}$ and $-46^{\circ} \mathrm{C}$. The results indicated both the FX-5 weld metal and the HAZ have sufficient toughness.

\section{Microstructure Analysis of the FX-5 Weld}

Microstructural analysis of the FX-5 weld was conducted to determine if any observations could be made to explain the positive property and weldability results. Samples for optical images were prepared using standard metallographic procedures, etched in $2 \%$ Nital for $10 \mathrm{~s}$ and then tinted in a solution of 20 g sodium metabisulfite in $100 \mathrm{~mL}$ water for $\sim 5 \mathrm{~s}$. Figure 12 shows a typical fusion area image of the weld. Progressing from left to right, this image shows a weld metal with a dendritic structure, a coarse-grained heat-affected zone (CGHAZ) adjacent to the fusion boundary and the base HMS steel microstructure at the right.

Scanning electron microscopy of the weld metal was performed - Fig. 13A and B. Figure 13A shows a dendritic microstructure with solidification grain boundaries clearly displayed. At the higher magnification (Fig. 13B), second-phase particles can be observed. Particles in the weld metal were of particular interest because the HMS chemistries are potentially prone to toughness degradation due to $\mathrm{Cr}$ carbide formation. It was determined, however, that these particles were oxide inclusions of the type commonly present in gas metal arc welds. Their size and volume fraction are relatively small, which was attributed to the Ar-based shielding gas and the low heat input $(\sim 1 \mathrm{~kJ} / \mathrm{mm})$ welding procedure. The presence of these inclusions was inconsequential to the properties as evidenced by the CVN results shown in Table 7 $\left(\sim 70 \mathrm{~J}\right.$ at $\left.-46^{\circ} \mathrm{C}\right)$. Electron backscatter diffraction (EBSD) analysis of the weld metal (Fig. 14) confirmed the formation of austenite and no ferrite or the deleterious martensitic phases were indexed. This confirmed the intended mi- crostructural design was achieved and the metastable variations, which can degrade toughness, were avoided. It was concluded the austenitic matrix was the dominant microstructural feature that led to good toughness and a ductile fracture mode at very low temperatures.

The elemental maps of three major alloying elements, Mo, $\mathrm{Cr}$, and $\mathrm{Mn}$, in the FX-5 weld metal are shown in Fig. 15A-C. It can be seen that these elements segregate into the interdendritic regions, which is a result of solute redistribution between solid and liquid during the austenitic solidification. The oxides inclusions were found to contain $\mathrm{Cr}$, Mo, and $\mathrm{Mn}$.

Unlike conventional low-carbon steels, the HMS HAZ had a coarse-grained heat-affected zone (CGHAZ) but no finegrained HAZ (FGHAZ) or intercritical HAZ (ICHAZ). There was no phase transformation from austenite to ferrite in the HAZ because the austenite was stabilized, thus grain growth occurred in response to the welding thermal energy. As shown in Fig. 12, the grain size of the CGHAZ was approximately 65 $\mu \mathrm{m}$, almost fourfold of that of the HMS base metal. In the region between the CGHAZ and base metal, the grain growth was restricted by precipitates, as shown in Fig. 16.

Transmission electron microscopy (TEM) was performed to study the HAZ precipitates. Figure $17 \mathrm{~A}$ and $\mathrm{B}$ shows the bright-field, high-magnification image and the corresponding selected area diffraction pattern (SADP), respectively. It can be clearly seen that carbides precipitated along the grain boundaries. The SADP indicates the precipitates had an FCC structure and they were in a cube-cube orientation relationship with the austenite matrix, as indicated below.

$\{001\} \gamma / /\{001\} \mathrm{M}_{23} \mathrm{C}_{6}$

$<001>\gamma / /<001>\mathrm{M}_{23} \mathrm{C}_{6}$

The precipitates were determined to be $M_{23} C_{6}$, with $M$, including $\mathrm{Fe}, \mathrm{Cr}, \mathrm{Mo}$, and $\mathrm{Mn}$. With the proper control of the 

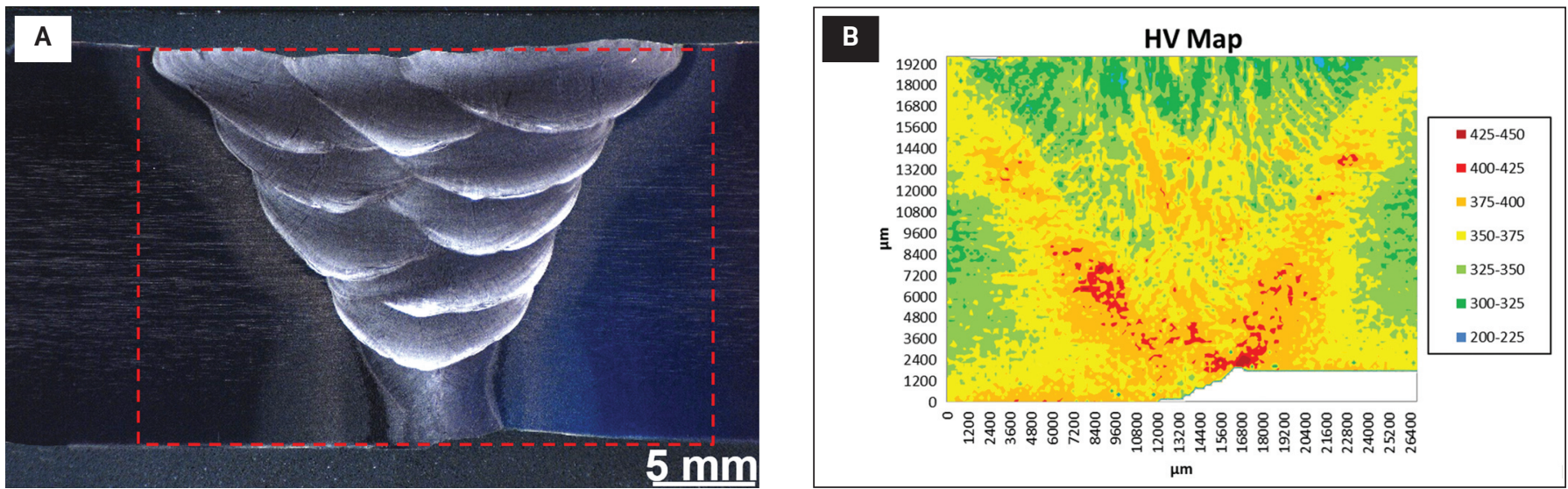

Fig. $18-A-F X-5$ girth weld macro, red dotted area indicating where the hardness mapping test was performed; $B$ - hardness mapping result.

welding procedures, especially the heat input, the grain growth and the carbide precipitation were moderate and did not cause the CVN toughness to drop below the required 27 $\mathrm{J}$ at $-29^{\circ} \mathrm{C}$ (Table 7$)$.

Vickers hardness testing was performed on the FX-5 weld per ASTM E 384-11 (Ref. 64) with a 500-g load and a 200$\mu \mathrm{m}$ indent spacing - Fig. 18A. The resulting hardness map is shown in Fig. 18B. It can be seen there was no softening in the weld metal or HAZ. Instead, slight hardening occurred in the weld root area. This could be attributed to the higher $C$ content in the weld root compared with the fill passes as a result of the weld dilution from the HMS base steel, which contains a higher $C$ content than the consumable. Because the weld root is exposed early to the erosive slurry environment, a harder weld root is preferred on the condition the higher hardness is not at the expense of toughness. As previously mentioned, the CVN results (Table 7) demonstrated the weld metal obtained good toughness.

\section{Commercial Field Application}

The HMS welding technology was applied commercially for the first time in July 2016 during the fabrication of approximately $1 \mathrm{~km}$ of HMS slurry pipeline at the Kearl Oil Sands Mining Operation in Alberta, Canada. This included use of the girth welding procedures described above and the FX-5 welding consumable. Twelve-meter- (40-ft-) long sections of HMS pipe were joined by girth welding to produce "double joints" of pipe $24 \mathrm{~m}$ ( $80 \mathrm{ft}$ ) in length. The fabrication activities were completed without any weldability problems (cracking) and the project was under budget and ahead of schedule. Figure 19 shows a photograph of an installed section of HMS slurry pipeline. As of the writing of this paper, the 1-km HMS slurry pipeline is still in operation. Field erosion/wear performance of the base pipe and girth weld have been verified. Based on this field application, the HMS slurry pipes have performed $3 \sim 5$ times better than the traditional carbon steel pipes. Larger scale HMS slurry pipeline installation is underway. Field application of this technology demonstrates the developed technology can enable use of HMS slurry pipes, which are now commercially available, to reduce the cost of oil sands slurry pipeline operations.

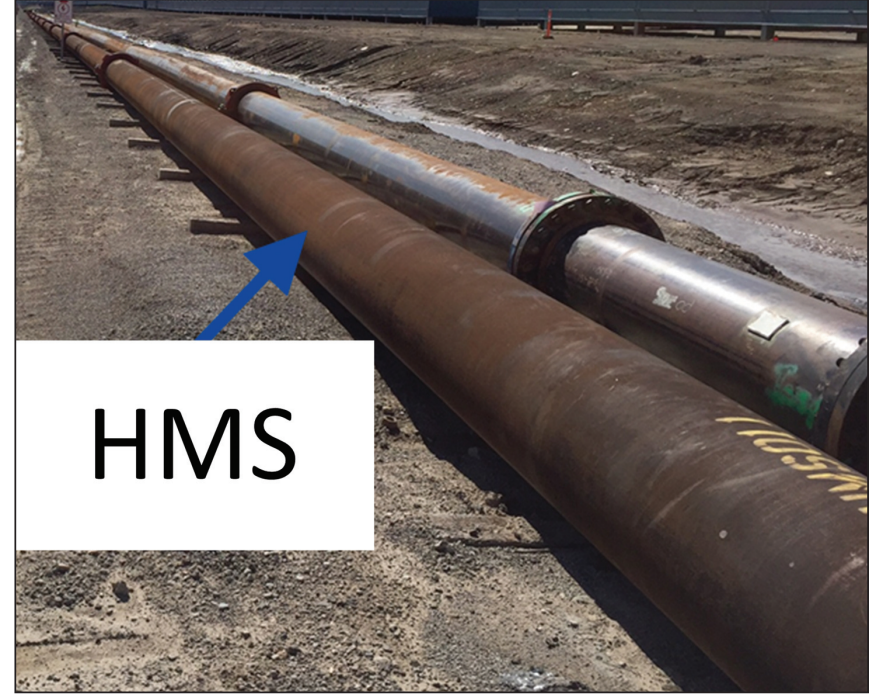

Fig. 19 - Photograph of HMS slurry pipes installed at Kearl Oil Sands Mining Operation. Fabrication was conducted using the developed welding consumable and procedures.

\section{Conclusions}

This paper described the development of welding technology for successfully enabling a new erosion-resistant HMS for slurry pipeline applications. The technology is expected to result in significant cost savings.

For the development of the welding consumable, eight alloying elements (with three concentrations for each element) were selected to create a matrix of 6561 welding consumable chemistries. Thermodynamic simulations were performed on these chemistries to calculate their SFE, STR, and CST. A DoE approach was used to evaluate the effect of the alloying elements on the three key thermodynamic parameters. The results were used to select 16 consumable chemistries from which experimental weld wires were made and tested (tensile, CVN, erosion resistance, DTA). A consumable named FX- 5 was selected as the best performing wire due to its superior combination of strength, toughness, erosion resistance, and solidification cracking resistance. 
Welding procedures for joining HMS pipes were developed using the FX-5 wire. A short circuit transfer mode was used for root welding and a pulsed spray transfer mode was used for the fill passes. Heat input was kept low $(\sim 1 \mathrm{~kJ} / \mathrm{mm})$ to minimize carbide precipitation and to reduce welding residual stresses. The final welding procedures were qualified per the project specification and ASME IX. These procedures achieved the demanding mechanical property targets and successfully avoided solidification cracking, a problem known to plague HMS welds.

Microstructure analysis indicated that the FX-5 weld metal consisted of dendritic austenite, with no presence of ferrite or the deleterious martensite. Grain growth and $\mathrm{M}_{23} \mathrm{C}_{6}$ carbide precipitation occurred in the HMS HAZ; however, they were moderate as a result of the welding procedure control and did not cause any toughness issues.

The developed HMS welding technology has been successfully applied for the fabrication of an erosion resistant HMS pipeline at the Kearl Oil Sands Mining Operation in Alberta, Canada. The performance thus far has met expectations; therefore, larger scale commercial deployment of this technology is underway. These pipelines are expected to display increased life and result in significant project cost savings.

\section{Acknowledgments}

The research was conducted under a Joint Development Agreement (EM07230) between ExxonMobil and POSCO. Thanks are extended to Dr. J. S. Lee, Dr. I. W. Han, Dr. J. K. Choi, Dr. J. S. Park, Dr. S. C. Lee and Dr. B. K. Lee with POSCO for manufacturing the consumables, providing the base HMS, and technical discussions. The following ExxonMobil personnel are acknowledged for their contribution: R. A. Berlin for the welding work; C. A. Harrell for taking optical images and performing hardness testing; J. M. Young for the materials shipping and handling; S. F. Sun for the jet impingement test; and A. Ozekcin for the EBSD work.

\section{References}

1. Humphries, M. 2008. North American oil sands: History of development, prospects for the future. Library of Congress Washington DC Congressional Research Service: 1-30.

2. Hojo, H., Tsuda, K., and Yabu, T. 1986. Erosion damage of polymeric material by slurry. Wear 112(1): 17-28. DOI: 10.1016/00431648(86)90197-3

3. Madsen, B. W. 1989. A comparison of the wear of polymers and metal alloys in laboratory and field slurries. Wear 134(1): 59-79. DOI: 10.1016/0043-1648(89)90062-8

4. Llewellyn, R., and Tuite, C. 1995. Hardfacing fights wear in oil sands operation. Welding Journal 74(3): 55-60.

5. Clark, H. M., and Llewellyn, R. J. 2001. Assessment of the erosion resistance of steels used for slurry handling and transport in mineral processing applications. Wear 250(1): 32-44.DOI: 10.1016/S0043-1648(01)00628-7

6. Neville, A., Reza, F., Chiovelli, S., and Revega, T. 2005. Erosioncorrosion behaviour of WC-based MMCs in liquid-solid slurries. Wear 259(1): 181-195. DOI: 10.1016/j.wear.2005.02.037

7. Flores, J. F., Neville, A., Kapur, N., and Gnanavelu, A. 2009. An experimental study of the erosion-corrosion behavior of plasma transferred arc MMCs. Wear 267(1): 213-222. DOI:10.1016/ j.wear.2008.11.015
8. Flores, J. F., Neville, A., Kapur, N., and Gnanavelu, A. 2009. Erosion-corrosion degradation mechanisms of $\mathrm{Fe}-\mathrm{Cr}-\mathrm{C}$ and WC-Fe- $\mathrm{Cr}-\mathrm{C}$ PTA overlays in concentrated slurries. Wear 267(11): 1811-1820. DOI: 10.1016/j.wear.2009.02.005

9. Jones, M., and Waag, U. 2011. The influence of carbide dissolution on the erosion-corrosion properties of cast tungsten carbide/Nibased PTAW overlays. Wear 271(9): 1314-1324. DOI: 10.1016/ j.wear.2011.01.046

10. Yang, Y., and Cheng, Y. F. 2012. Parametric effects on the erosion-corrosion rate and mechanism of carbon steel pipes in oil sands slurry. Wear 276: 141-148. DOI: 10.1016/j.wear.2011.12.010

11. Parent, L. L., and Li, D. Y. 2013. Wear of hydrotransport lines in Athabasca oil sands. Wear 301(1): 477-482. DOI: 10.1016/ j.wear.2013.01.039

12. Nguyen, Q. B., Lim, C. Y. H., Nguyen, V. B., Wan, Y. M., Nai, B., Zhang, Y. W., and Gupta, M. 2014. Slurry erosion characteristics and erosion mechanisms of stainless steel. Tribology International 79: 1-7. DOI: 10.1016/j.triboint.2014.05.014

13. Islam, M. A., Jiang, J. J., Xie, Y., and Fiala, P. 2017. Investigation of erosion-corrosion behavior of (WTi) C based weld overlays. Wear 390: 155-165. DOI: 10.1016/j.wear.2017.07.016

14. Enhanced wear resistant steel and methods of making the same. U.S. Patent Application 14/196,010.

15. Avery, H. S., and Chapin, H. J. 1954. Austenitic manganese steel welding electrodes. Welding Journal 33(5): 459-s to 479-s.

16. Chan, J. W., Sunwoo, A. J., and Morris Jr, J. W. 1990. High-Mn steel weldment mechanical properties at $4.2 \mathrm{~K}$. Welding Journal 69(1): 30-s to 38-s.

17. Mendez, J., Ghoreshy, M., Mackay, W. B. F., Smith, T. J. N., and Smith, R. W. 2004. Weldability of austenitic manganese steel. Journal of Materials Processing Technology 153-154: 596-602. DOI: 10.1016/j.jmatprotec.2004.04.033

18. Yildizli, K., Eroglu, M., and Karamiş, M. B. 2007. Microstructure and erosive wear behavior of weld deposits of high manganese electrode. Surface and Coatings Technology 201(16): 7166-7173. DOI: 10.1016/j.surfcoat.2007.01.024

19. Mujica, L., Weber, S., Thomy, C., and Vollertsen, F. 2009. Microstructure and mechanical properties of laser welded austenitic high manganese steels. Science and Technology of Welding and Joining 14(6): 517-522. DOI: 10.1179/136217109X434243

20. Efstathiou, C., and Sehitoglu, H. 2009. Strengthening Hadfield steel welds by nitrogen alloying. Materials Science and Engineering A 506(1): 174-179. DOI: 10.1016/j.msea.2008.11.057

21. Mujica, L., Weber, S., Pinto, H., Thomy, C., and Vollertsen, F. 2010. Microstructure and mechanical properties of laser-welded joints of TWIP and TRIP steels. Materials Science and Engineering A 527: 2071-2078. DOI: 10.1016/j.msea.2009.11.050

22. Roncery, L. M., Weber, S., and Theisen, W. 2012. Welding of twinning-induced plasticity steels. Scripta Materialia 66(12): 997-1001. DOI: 10.1016/j.scriptamat.2011.11.041

23. Matsuda, F., Nakagawa, H., and Sorada, K. 1982. Dynamic observation of solidification and solidification cracking during welding with optical microscope. Transactions of JWRI 11(2): 67-77.

24. Lippold, J. C., and Savage, W. F. 1982. Solidification of austenitic stainless steel weldments: Part III - the effect of solidification behavior on hot cracking susceptibility. Welding Journal 61(12): 388-s to 396-s.

25. Feng, Z. 1994. A computational analysis of thermal and mechanical conditions for weld solidification cracking. Welding in the World 33(5): 340-347. DOI: 0043-2288(94)E-00032-8

26. DuPont, J. N., Robino, C. V., and Marder, A. R. 1998. Solidification and weldability of Nb-bearing superalloys. Welding Journal 77(10): 417-s to 431-s.

27. Kou, S. 2003. Solidification and liquation cracking issues in welding. JOM Journal of the Minerals, Metals and Materials Society 55(6): 37-42. DOI: 10.1007/s11837-003-0137-4

28. Lippold, J. C. 2005. Recent developments in weldability test- 
ing. Hot Cracking Phenomena in Welds. pp. 271-290. Springer Berlin Heidelberg. DOI: 10.1007/3-540-27460-X_14.

29. Babu, S. S. 2009. Thermodynamic and kinetic models for describing microstructure evolution during joining of metals and alloys. International Materials Reviews 54(6): 333-367. DOI: 10.1179/095066009X12506720908654

30. Lippold, J. C. 2014. Welding Metallurgy and Weldability. , John Wiley \& Sons Inc., pp. 84-129.

31. Sutton, B. J., and Lippold, J. C. 2013. Effect of alloying additions on the solidification cracking susceptibility of high manganese steel weld metals. Proc. 23 ${ }^{\text {rd }}$ Int'l Offshore and Polar Eng. Conf. Anchorage, Alaska: pp. 340-347.

32. Han, I. W., Lee, B. K., Choi, J. K., Park, S. H., and Kang, C. Y. 2013. Microstructure and mechanical properties of cryogenic highmanganese steel weld metal. Proc. $23^{r d}$ Int'l Offshore and Polar Eng. Conf. Anchorage, Alaska: pp. 348-352.

33. Han, K., Yoo, J., Lee, B., Han, I., and Lee, C. 2014. Effect of Ni on the hot ductility and hot cracking susceptibility of high $\mathrm{Mn}$ austenitic cast steel. Materials Science and Engineering A 618: 295-304. DOI: 10.1016/j.msea.2014.09.040

34. Yoo, J., Han, K., Park, Y., Choi, J., and Lee, C. 2014. Evaluation of solidification cracking susceptibility of Fe-18Mn-0.6C steel welds. Science and Technology of Welding and Joining 19(6): 514-520. DOI: 10.1179/1362171814Y.0000000216

35. Yoo, J., Kim, B., Park, Y., and Lee, C. 2015. Microstructural evolution and solidification cracking susceptibility of Fe-18Mn-0.6CxAl steel welds. Journal of Materials Science 50(1): 279-286. DOI: 10.1007/s10853-014-8586-4

36. Lenzo, J. C., and Lippold, J. C. 2016. Effect of alloying additions on the microstructure and solidification cracking susceptibility of high-manganese steel filler metals. Proc. $26^{\text {th }}$ Int'l Offshore and Polar Eng. Conf. Rhodes, Greece: pp. 170-177.

37. Choi, J. K., Lee, S. G., Park, Y. H., Han, I. W., and Morris Jr., J. W. 2012. High manganese austenitic steel for cryogenic applications. Proc. 22 ${ }^{\text {nd }}$ Int'l Offshore and Polar Eng. Conf. Rhodes, Greece: pp. 29-35.

38. Oshima, T., Habara, Y., and Kuroda, K. 2007. Efforts to save nickel in austenitic stainless steels. ISIJ International 47(3): 359-364. DOI: 10.2355/isijinternational.47.359

39. Saeed-Akbari, A., Mosecker, L., Schwedt, A., and Bleck, W. 2012. Characterization and prediction of flow behavior in high-manganese twinning induced plasticity steels: Part I. Mechanism maps and work-hardening behavior. Metallurgical and Materials Transactions A 43(5): 1688-1704. DOI: 10.1007/s11661-011-0993-4

40. Pierce, D. T., Jiménez, J. A., Bentley, J., Raabe, D., Oskay, C., and Wittig, J. E. 2014. The influence of manganese content on the stacking fault and austenite/ $\varepsilon$-martensite interfacial energies in $\mathrm{Fe}$ $\mathrm{Mn}$-(Al-Si) steels investigated by experiment and theory. Acta Materialia 68: 238-253. DOI: 10.1016/j.actamat.2014.01.001

41. Tomota, Y., Strum, M., and Morris, J. W. 1986. Microstructural dependence of Fe-high Mn tensile behavior. Metallurgical Transactions A 17(3): 537-547. DOI: 10.1007/BF02643961

42. De Cooman, B. C., Kwon, O., and Chin, K. G. 2012. State-ofthe-knowledge on TWIP steel. Materials Science and Technology 28 (5): 513-527. DOI: 10.1179/1743284711Y.0000000095

43. Easterling, K. 1992. Introduction to the Physical Metallurgy of Welding. pp. 1-15, Oxford, UK: Butterworth-Heinemann Ltd.

44. Jeong, K., Jin, J. E., Jung, Y. S., Kang, S., and Lee, Y. K. 2013. The effects of $\mathrm{Si}$ on the mechanical twinning and strain hardening of Fe-18Mn-0.6C twinning-induced plasticity steel. Acta Materialia 61(9): 3399-3410. DOI: 10.1016/j.actamat.2013.02.031

45. Morris, J.W. 2013. Iron-manganese steels for cryogenic use. Proc. 23 ${ }^{\text {rd }}$ Int'l Offshore and Polar Eng. Conf. Anchorage, Alaska: pp. 322-329.

46. Lippold, J. C., and Kotecki, D. J. 2005. Welding Metallurgy and Weldability of Stainless Steels. pp. 19-39, John Wiley \& Sons, Inc.

47. Simmons, J. W. 1996. Overview: High-nitrogen alloying of stainless steels. Materials Science and Engineering A 207(2): 159-169.
DOI: 10.1016/0921-5093(95)09991-3

48. DuPont, J. N., Lippold, J. C., and Kiser, S. D. 2009. Welding Metallurgy and Weldability of Nickel-Base Alloys. pp. 15-45, John Wiley \& Sons Inc.

49. Park, K. T., Jin, K. G., Han, S. H., Hwang, S. W., Choi, K., and Lee, C. S. 2010. Stacking fault energy and plastic deformation of fully austenitic high manganese steels: Effect of Al addition. Materials Science and Engineering A 527(16): 3651-3661. DOI:

10.1016/j.msea.2010.02.058

50. Hwang, S. W., Ji, J. H., and Park, K. T. 2011. Effects of Al addition on high strain rate deformation of fully austenitic high $\mathrm{Mn}$ steels. Materials Science and Engineering A 528(24): 7267-7275. DOI: 10.1016/j.msea.2011.06.020

51. Sundman, B. 2001. Thermo-Calc. S-100 44[[N]]. Stockholm, Sweden, Department of Materials Science and Engineering, KTH.

52. Saunders, N. 2001. Fe-Data Thermodynamic Database. [[3.0]] The Surrey Research Park, Guildford, UK, Thermotech Ltd.

53. Olson, G.B., and Cohen, M. 1976. A general mechanism of martensitic nucleation: Part I. General concepts and the FCC $\rightarrow \mathrm{HCP}$ transformation. Metallurgical Transactions A 7(12): 1897-1904. DOI: 10.1007/BF02659822

54. Saeed-Akbari, A., Imlau, J., Prahl, U., and Bleck, W. 2009. Derivation and variation in composition-dependent stacking fault energy maps based on subregular solution model in high-manganese steels. Metallurgical and Materials Transactions A 40(13): 3076-3090. DOI: 10.1007/s11661-009-0050-8.

55. Bouaziz, O., Allain, S., Scott, C. P., Cugy, P., and Barbier, D. 2011. High manganese austenitic twinning induced plasticity steels: A review of the microstructure properties relationships. Current Opinion in Solid State and Materials Science 15(4): 141-168. DOI:

10.1016/j.cossms.2011.04.002

56. Allain, S., Chateau, J. P., Bouaziz, O., Migot, S., and Guelton, N. 2004. Correlations between the calculated stacking fault energy and the plasticity mechanisms in Fe-Mn-C alloys. Materials Science and Engineering A 387: 158-162. DOI: 10.1016/j.msea.2004.01.059

57. Dumay, A., Chateau, J. P., Allain, S., Migot, S., and Bouaziz, O. 2008. Influence of addition elements on the stacking-fault energy and mechanical properties of an austenitic Fe-Mn-C steel. Materials Science and Engineering A 483: 184-187. DOI:

10.1016/j.msea.2006.12.170

58. Kannengiesser, T., and Boellinghaus, T. 2014. Hot cracking tests - An overview of present technologies and applications. Welding in the World 58(3): 397-421. DOI: 10.1007/s40194-014-0126-y

59. ASTM E8/E8M-16a: 2016. Standard Test Methods for Tension Testing of Metallic Materials. ASTM International, West Conshohocken, $\mathrm{Pa}$.

60. ASTM E23-12c: 2013. Standard Test Methods for Notched Bar Impact Testing of Metallic Materials. ASTM International, West Conshohocken, Pa.

61. ASME B31.11: 2002. Slurry Transportation Piping Systems. American Society of Mechanical Engineers, New York, N.Y.

62. Kou, S. 2003. Welding Metallurgy. pp. 263-295, Hoboken, N.J., John Wiley \& Sons Inc.

63. ASME Section IX: 2013. Qualification Standard for Welding, Brazing, and Fusing Procedures; Welders; Brazers; and Welding, Brazing, and Fusing Operators. American Society of Mechanical Engineers, New York, N.Y.

64. ASTM E 384-11: 2011. Standard Test Method for Knoop and Vickers Hardness of Materials. ASTM International, West Conshohocken, $\mathrm{Pa}$.

XIN YUE (xin.yue@exxonmobil.com), ANDREW J.WASSON, and TIMOTHY D. ANDERSON are with EXXONMobil Upstream Research Co., Spring, Tex. NING MA and HYUNWOO JIN are with EXXonMobil Research and Engineering Co., Clinton, N.J. DOUG P. FAIRCHILD is with ExxonMobil Upstream Engineering, Spring, Tex. 